\title{
The signified as a reflex of language contacts
}

\author{
Enikő Pál* \\ Faculty of Economic and Human Sciences, Sapientia University, Piața Libertății 1, 530104 Miercurea Ciuc, Romania
}

\section{Article info}

Istoric:

Received May 30, 2014

Accepted June 29, 2014

Published January 13, 2015

Key words:

language contact

lexical borrowing

Old Romanian literary

language

\begin{abstract}
The present study joins the series of works aiming to bring up to date, within Romanian linguistics, the theories concerning (Romanian-Hungarian) linguistic interferences manifested in bilingual communities and the research of lexical properties which have entered the Romanian written language either by the influence of the Hungarian dialects, spoken in different regions of the country, or by the translation of Hungarian texts into Romanian. The study will focus on Hungarian loanwords in old Romanian language which are discussed in terms of their changes in meaning. The inventory of the Hungarian loanwords' meanings listed here was made based on a corpus of old Romanian texts, taking into account the material provided by various dictionaries with etymological concerns. As the few examples analysed in this study show, lexical meaning is impregnated with both intellect and emotional sensibility. The emotional universe, however, is rarely taken over along with the loanword. The emotional content is most often adapted, in its turn, to the sensitivity and spirituality of the speakers who borrowed the word.
\end{abstract}

Motto: "If you look closely at a grain of wheat you shall find the face of Jesus in it", as an old saying goes (Izvorul. Revistă de etnografie și folclor, nr. 30, Giula, 2009, p. 22). Just as spiritual life and death are encapsulated in the simplicity of a wheat grain, one single word may spread out a whole universe of thoughts and feelings.

\section{Psychology and historical linguistics. Preliminaries}

The idea that language, psyche and national spirit represent inextricably merged entities has been present in language sciences for a long time, being explicitly formulated by W. von Humboldt. Thus, "language acquires its final determination only in the individual" (Humboldt, 1836/2008, p. 99), on the one hand, and "each language embodies a certain particular world view", in other words, "each language contains the whole conceptual fabric and mode of representation of a portion of mankind" (ibidem, p. 95), on the other hand. If language reflects what a nation thinks and feels, then the variety of languages is, essentially, a reflex of spiritual diversity. These ideas, quite innovative in the days of the German linguist, nowadays close to commonplaces, have triggered an avalanche of psycholinguistic research, especially since the second half of the nineteenth century.

This paradigm shift in language sciences is relatively concurrent with the establishment of a new discipline within the field of psychology. Its premiss was the observation that the spirit of a community (with repercussions on language) should be regarded as being different from the individual spirit and, therefore, beside individual psychology, the existence of an ethnopsychology (Völkerpsychologie) should also be acknowledged. The new discipline have proposed to study those psychological principles and processes which underlie and govern social relations and the development of social and human life, on the one hand, and the emergence and evolution of the common spiritual products of a community resulted from social interaction, on the other hand. Among these products there figures language itself. But unlike the

*Email address: enikopaldr@gmail.com. 
historical approach to a certain linguistic form, such as a loanword, which would interest the researcher for it preserves the memory of a past relationship between two human communities, the ethnopsychological perspective interests the scientist only if the given form shows general human principles of language evolution.

The first attempts to provide psychological explanations for facts related to the development of language were made by Steinthal $(1855,1865)$. His work may be regarded as a programme of the new direction in which, for the first time, psychology replaces the philosophy of language. In the same direction enters Paul (1886), his succesor, according to whom linguistic phenomena should be explained by the spiritual interaction between man and his environment. In developing his system, the author uses the results provided by psychology for linguistic purposes. A somewhat different perspective is to be found in the work of Wundt (1904). Thus, he is less interested in linguistic facts itself, being concerned about how psychological processes and principles result from them. In other words, for him historical linguistics represents a substantial material which can be used to explain various psychological phenomena.

Whether we explain linguistic phenomena by psychological mechanisms or we pursue the opposite approach, the interdependence between language - thought - society remains indisputable. Language undoubtedly reflects the universe of representations and mental associations characteristic for a community and, thus, the substantiality of the vocabulary of a given language relatively corresponds to the amount of the mental representations of the community who speaks that very language. In the same manner, word formation and the morphosyntactic relations between words in a language allow us to see the principles and forms of mental associations which are allowed and practised within the community. In this sense, in the semantic changes of words it is manifested, in fact, the principle of representation shift.

Language being the supreme instrument of a community's consciousness, the historical and the psychological approaches to language, although pursue different purposes, can not be regarded as two entirely separate entities but as two perspectives which support and complete each other. Therefore, notwithstanding that diachronic linguistics is interested in language mainly as a historical phenomenon rather than as a psychological one, the psycholinguistic study of language may be extremely fruitful for researches in the history of language (see also Gombocz, 1898).

\section{The psychological side of the word}

From a psychological perspective, every word is a combination of different mental representations, a "complication" of them, i.e. a simultaneous connection between disparate representations (cf. Wundt, 1893, p. 209; Gombocz, 1997, p. 134). Hence, the sound pattern (signifier) involves the combination of two types of representations: an acoustic image (= the sensory representation of the sound, i.e. the perception of sounds: we hear what we and others say) and a dynamic image (= the representation of a motion sensation, i.e. the articulation of sounds: we feel how our vocal tract, muscles, etc. function). The other constituent of a word's "complication" is the conceptual image (signified), that substance of the representation which the speaker and the listener associate with the name. In case of the literates, these two types of representations are supplemented by graphic representations of the word which combines the representations of the letters that make up the sound pattern and the representations of writing movements. In other words, each word involves two sensory images (auditory and visual) and two motor images (oral and manual) (cf. Vendryes, 1921, p. 79).

There is a tight associative relationship between the image of the sound pattern and its conceptual image. This explains the evocative power of the signifier. Within a community, the speaker associates the same or almost the same notional content with an articulated sound pattern as the listener does. The understanding between the speaker and the listener may have various degrees, depending on whether this content is identical or only similar for the two interlocutors.

A word, however, does not only have an evocative power, but it may also have a disposition and mood inducing force. In other words, the meaning associated with a phonetic pattern is not only made up 
of notional representations, but it also has emotional elements within it (for the phenomena of emotional elements in words see Zolnai, 1920: szóhangulat; Simonyi, 1916: érzelmi velejáró; Wundt, 1904: Gefühlston, Gefühlswert der Worte; Bally, 1926: valeur affective). An affective value may have both the notional content of the representation and the sound pattern, which, in its turn, is the result of a historical development just like the signified or the signifier. Influenced by its content or independent of it, the articulated speech sounds may induce a certain state of mind, like musical sounds do. This aesthetic effect is usually achieved by the word's sonority, i.e. by the alternation, distribution and sequence of voiced and voiceless sounds. Beside the quality of sounds ${ }^{1}$, a pleasant or unpleasant sensation may also be produced by stress, intonation and rhythm of speech, by which different words are perceived as being pleasant or unpleasant, beautiful or ugly. For instance, Hung. szello' 'breeze' is perceived, in accoustic terms, as being pleasant, beautiful and harmonious, whereas Hung. kecsegtet 'deceives, promises' is unpleasant to hearing and perceived as being ugly. Another interesting situation is when each lexeme in a synonymous pair of words is associated with different affective values. For instance, in Hungarian, the words apa 'father, (male) parent' and atya '(male) parent, father', although designate the same notional content, functioning, from a logical perspective, as synonyms, have different affective values, arousing unalike emotions (cf. Gombocz, 1997, p. 102, 139). This difference has been signaled in the dictionary of Czuczor \& Fogarasi, where the following observation is made: "regarding their usage, the distinction between apa and atya seems to be that apa is employed rather colloquially, it enjoys greater popularity and suggests familiarity, while atya sounds more mannered, it suggests respect, being used to designate persons mainly of a (high) position or rank" (s.v. atya). The nature of the emotional content associated with each one of these words determines their contexts of usage. Thus, apa is employed when seeking the intimate, confidential and affectionate nature of a relationship (cf. édesapám 'my sweet father', Kossuth apánk 'our father Kossuth'), when designating the father - child relationship without any emotional tone (cf. az apjára ütött 'he/she resembles his/her father') or in harsh and insulting expressions, in imprecations of folk common language (cf. az apád istenit! 'for God's sake!'). In contrast, atya is employed when the dominant sentiment is that of respect, in contexts of solemnity (cf. uram atyám 'Lord God, my Father', Miatyánk 'Our Father (the prayer)', lelki atya 'spiritual father (confessor)', a haza atyja 'father of the nation').

Loanwords obviously represent quite a particular situation. On the one hand, these carry the conceptual and emotional associations characteristic for the community which provided them, since these associations are reflected in the source language, i.e. in the etymon. On the other hand, these words live a distinct life in the target language, being adapted to the conceptual and emotional universe of the community which borrowed them. Thus, it is understandable that not only the notional representations (i.e. the meaning of the loanwords) may change, but also the attitudes manifested towards the physical world which these words reflect, irrespective of whether they had been previously known in the target community or not. At the same time, the phonetic pattern itself may be charged with new emotional and expressive values, on the one hand, because the sounds of the target language have other phonetic peculiarities (other articulatory features, other distribution, etc.) than the (quasi-)correspondent sounds of the etymon and, on the other hand, because the loanword often appears in the target language as an unanalysable lexeme which no longer allows the componential analysis which was possible in the case of the etymon ${ }^{2}$.

\footnotetext{
${ }^{1}$ The quality of a sound may carry not only an expressive value but also a notional content. In Finno-Ugric languages, also conditioned by vowel harmony, the vowels in the palatal - velar pair are associated with different conceptual contents or, in any case, with different nuances. Thus, for instance, in the case of the demonstrative pronoun, the velar variant is associated with the mental representation or the concept 'long(er) distance', while the palatal variant implies the meaning 'short(er) distance' (see Hung. $\boldsymbol{e} z$ 'this' - az 'that', itt 'here' - ott 'there', ide 'hither' - oda 'thither', ilyen 'this kind (of)' - olyan 'that kind (of)', igy 'like this, for this reason' - úgy 'like that, for that reason', etc.). Similarly, in the case of verbs or nouns, the synonymous pairs are differentiated in that the palatal and velar variants are associated with different representations of intensity (see Hung. kever

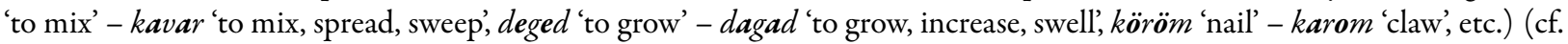
Gombocz, 1997, p. 136).

${ }^{2}$ For instance, in Rom. răvaş 'letter, note, document' one could hardly find, if at all, the Hungarian derivative róvás 'notch,
} 


\section{The psychological side of semantic changes}

Semantic changes are essentially psychological processes. When explaining the changes of the signified one must inevitably take into account several extralinguistic factors, such as the actual or perceived as being actual attributes of the designated object, its function within the culture which designated it, its role played within the socio-interpretative system, as well as other cognitive, emotional, etc. factors which determin the interpretation of those who employ the linguistic sign, and sometimes even the arbitrary despotism of different individuals, as Bréal (1897) observed.

The explanations of semantic changes often invoked the "historical accident", considering that meaning shifts occur inevitably and sometimes unfounded. This kind of approach to the phenomenon of semantic change was refuted by Wundt (1904). According to the German psychologist, the changes which occur in the signified are not random, but they comply with strict principles, only the processes involved may not always be explained. Thus the author distinguishes two types of semantic changes: regular and singular (sporadic). The former represent the actual semantic changes, in the strict sense of the word, which appear as a result of a slow and steady process, whose causes should be sought in the attributes of the concept subjected to change, being produced, therefore, as a consequence of the changes occurred within the mental associations which work in each and every member of the community, just like instinctive acts. Singular changes, on the other hand, constitute spontaneous transfer situations which occur without interim phases, starting usually from certain individuals of the community and which are brought about by arbitrary acts. In other words, the former ones reflect the history of a concept, whereas the latter ones represent first of all the history of a word and secondly the history of the concept designated by the word. A drawback of this theory is that the meaning (signified) is looked upon as an equivalent of the concept designated by the signifier and, therefore, the semantic change reflects, according to W. Wundt, the change of the concept. The meaning of a word, however, seems to be rather a functional concept and semantic changes should be regarded, thus, as changes of the signified, produced that is to say in the denotation (= current lexical meaning) and not in the notion per se, or at least not absolutely necessarily (cf. Gombocz, 1997, p. 166). Nevertheless, it is to the credit of W. Wundt that a new approach has been introduced to the discussion on semantic change, which proved to be extremely fruitful for subsequent researches.

Most classifications of semantic changes are limited to the identification of the departure point, i.e. the primary meaning, and of the arrival point, i.e. the meaning derived from the former one, but none of these were able to explain neither the causes of these shifts from one meaning to another, nor the processes involved in this endeavour, so that the classifications thus obtained are often purey formal. Neither Paul (1886) could be free from such a formalisation of the description. The types of semantic changes dissociated by him take into account the logical relationship between the primary and the derived meanings, differentiating, thus, situations of superordination (broadening of meaning), subordination (narrowing of meaning) and coordination (metonymic transfer). Despite the utility of these concepts, the issues raised by semantic progression are not solved by them, all the more so because these criteria do not explain the causes which trigger the changes or, in any case, not in all their complexity. For instance, it is known that a semantic extension has its starting point in the existence of at least one common semanteme, but the direction in which the different semantemes develop is not longer under the control of any regularity. In other words, there is nothing in the semanteme itself which would impose on a semantic nucleus to follow a given direction and to develop a particular nuance rather than another. In the case of meaning narrowing, the signified loses one or more of its constituent semantemes, which in most cases leads to the specialisation of the lexeme in a particular semantem. Neither in this case, however, the choice of a particular semanteme exploited over another is not governed by linguistic reasons (only), which makes

writing' from which it derives (< ró- 'to write' + noun suffix - $(v)$ ás), and it is not even a derivative word in Romanian language. Similarly, Rom. răzăş (răzeş) 'free peasant (in the Middle Ages, in Moldavia)' resulted from the adaptation of the Hungarian derivative részes 'the one who has a part/share in something' (< rész- 'part, share' + noun/adj. suffix - es), in Romanian, however, it is not a derivative (cf. sămăraş, sechiraş, etc.). 
the change unpredictable. Another noteworthy contribution to the research of diachronic semantics was made by Meillet (1905-1906, 1948), who introduces the socio-historical criteria into the explanation of semantic changes. Thus, the author takes into account the complexity of the changes and developments occured in the social and cultural life of men, in the social structure of the linguistic community, in the class and group based stratification of language, analysing their effects on each other. As a matter of fact, this interpretation, in its turn, has certain drawbacks since the changes of the cultural and social conditions constitute only one of the possible causes, by no means necessary, of the changes occured in the mental representations and associations, and their impact on the processes of the meaning shift is only indirect.

\section{Semantic changes of Hungarian loanwords in Romanian language}

To put it simply, the semantic change of a given word may be described by the following formula: Ax > Axy > Ay (cf. Gombocz, 1997, p. 104), where A represents the phonetic pattern with which a notional representation $\mathrm{x}$ is associated. Depending on various factors, with A may be associated another notional content too, represented by $\mathrm{y}$, but if and only if there is an associative relationship between $\mathrm{x}$ and $\mathrm{y}$. Eventually, A is employed with y meaning, whether replacing Ax which has been overused and eliminated, or coexisting with it, i.e. both $A x$ and Ay are maintained. When a changing in the dominant representation, i.e. the constant notional content of a word, occurs, the awareness of the etymological ties of the word also fades, that is to say, it loses its connections with other words to which it had been semantically and/or formally related ${ }^{3}$.

The semantic changes of Hungarian loanwords in Romanian language have, once again, a set of peculiarities quite its own. Hungarian loanwords are the product of contacts between the two linguistic communities, and as such they are the materialisation, at least at the beginning of their existence in the Romanian language, of two more or less different universes of representations and of mental and emotional associations. The lexical element borrowed from Hugarian language naturally keeps at first its etymological meaning in Romanian as well ${ }^{4}$, after which it may undergo various semantic shifts, developing meanings different from those in Hungarian, and sometimes even eliminating partially or completely its primary meanings, or at least some of its nuances.

It is not absolutely necessary, however, for a certain loanword to develop new meanings within the language it enters. A Hungarian loanword may as well carry on with its network of semantic relations existent in Hungarian language. Likewise, the causes and the means by which a particular nuance of the signified achieves positive or negative connotations are extremely varied, and its explanation is not limited to linguistic factors only. The psychological and subjective perceptions of the speakers largely determin the assignment of connotated meanings.

In any event, the mechanisms by which Hungarian loanwords generate new meanings of its own are

\footnotetext{
${ }^{3}$ For instance, in the case of Hung. lábos '(sauce)pan', although the awareness of its etymological ties is not completely lost, a componential analysis being still possible (<láb 'foot' + noun suffix -as), its past notional representation, in which the cookware was literally standing on feet and thus leaning over the open fire, has obviously changed (cf. MESz, s.v.). The Hung. szélhámos, which initially designated 'the horse without harness which is tied to the edge of a cart to run alongside the horses which actually pull the cart' (cf. MESz, s.v.), and whose current meaning is 'impostor', seems to have lost both its etymological ties (since no one would recognise in it its components: szél 'edge' + hám 'harness' + adj. suffix -os), and its primary notional representation (cf. Gombocz, 1997, p. 110). The latter one could have faded among those individuals or communities who did not have close enough contacts with the material world involved (i.e. carts and horses). The shift to its current meaning '(person) who deceives, deludes' may be explained by the projection of the nuance 'appearance' on to other material realities with an outward misleading appearance, since the horse thus tied to the cart only apparently pulls it, confusing, deceiving the eyes/people.

${ }^{4}$ Undoubtedly, all loanwords acquire or develop its own meanings dependening on the conceptual domain of its etymons. In some of the cases, this dependence is decisive and final, the loanword making use exclusively or almost exclusively of the semantic values offered by the etymon, without employing its own productivity. In some other cases, the loanword is freed from the notional constraints imposed by the semantic sphere circumscribed by its etymon and it develops with a spectacular (auto-)generating power its own meanings.
} 
similar to those employed in the case of any other words of the Romanian language (inherited or of other origins). The speakers who borrow the lexeme exhaust all its meanings and contexts, the more so if they are in vivid contacts with those whom they borrowed it from. Both the former and the latter ones exploit all the valencies of a term, although the final point reached in one or in the other of the two languages may be different.

The capacity to develop new meanings, often unrelated to its etymological meaning, characterises both bilinguals and monolinguals, but the former ones have the opportunity to use to a greater extent the potential valencies included in the etymon. At the same time, they retain much more of the nuances included in a semantic nucleus and preserve the etymological meanings for longer. At those who do not maintain direct and permanent contacts with Hungarian speakers, the changes operated on the lexical items are more pronouncedly present, and the loanwords are used in limited contexts, with restricted meanings required obviously by their communicative needs. Therefore, it is only natural that, in case of major semantic changes, the etymological meanings are preserved in the regions influenced, nowadays and/or in the past, by the Hungarians, and the most distant meanings from those included in the etymon are spread within the areas less or not at all affected by Hungarian influence. As might be expected, the latter ones have been adopted in most cases by the Romanian literary language.

4.1. The direction in which a certain conceptual domain of a loanword is pushed within the target language may be totally different from that in which it started off and to which the etymon adheres in the source language. Such an interesting case is that of the Romanian term adămană (< Hung. adomány 'donatio, donum', MNYSZ, cf. EWUR, the $-\breve{a}$ ending deriving from a morphological variant of the Hungarian word, probably from that with the genitive suffix $-(j) a)$. The Romanian loanword of Hungarian origin has developed quite a different meaning from that of the etymon, by which it has been placed in another connotative field. In Hungarian language, adomány signifies 'donation', 'what is given to someone as a gift or as a reward', implying, thus, a beneficiary thematic relation, i.e. a positive connotation. The thematic relations are somewhat different in Rom. adămană which in old Romanian texts is employed with the meaning 'usury, interest': “Argintul său nu va da într-adămană și plată nu va loa de la nevinovați” ['He that putteth not out his money to usury, nor taketh reward against the innocent'] ( $\left.\mathrm{PH}, 9^{\mathrm{v}} / 5\right)$. In this case, the meaning of the loanword assumes the existence of a debtor, implying, thus, a negative connotation. The meaning 'usury, interest' is preserved in the following centuries as well, being found in Transylvania, Maramureș (SD, s.v.) and Oaș (CADE, s.v.). The term has developed, perhaps later, the nuance of 'bribery temptation' (noted in CADE, SD, DLRLV, where see also the variant ademană), meaning out of which it could develop the current meaning of its verbal derivative a ademeni 'to deceive', 'to tempt, to lure' and even 'to seduce' (SD, DA, DER, TRDW, s.v.). Unlike the meanings developed within Romanian language by exploiting a secondary meaning contained in the Hungarian etymon, which are perfectly explicable from each other, explaining the transition from the primary, etymological, meaning, to the Romanian derived meaning encounters some difficulties. What may be noticed is that the Hungarian noun adomány fructifies the valencies of the verb from which it derives: ad 'to give' + noun suffix -(o)mány (cf. also ir 'to write' + -(o)mány). Such a componential analysis of the word may have been applied, although not absolutely necessarily, by the bilinguals who borrowed it, who could have been familiar with this method of forming words in Hungarian and who had countless opportunities to relate to and adjust (control) the foreign element right in its own source. In the absence of direct contacts with Hungarians or simply due to the fact that time went by, however, the Romanian term adămană became lexically unanalysable since its components do not have the same meaning in Romanian as they had in the etymon. Thus, it did not only lose track of its etymological ties, but it also lost its dominant mental representation included in the etymon. Be that as it may, it is quite difficult to determine what the precise cause was, due to which the meaning was pushed toward a completely different direction from that of the etymon.

4.2. Another situation is that of Rom. a adăvăsi (Rom. derivative < Hung. odavesz-ni 'pereo; zu grundé gehen', MNYSZ - 'to disappear', 'to lose sight', 'to (be) consume(d)' + verbal suffix $-i$; cf. N. Drăganu, DR, IV, 1924-1926, part 2, p. 752-753; cf. EWUR, p. 55-56). The primary meaning of the verb 
was most likely 'to scatter, to disperse' with which it was used in the sixteenth century. Thus, the meaning 'to scatter/destroy people' of the term is noted in PO: "Împărți-voiu pre ei în Iacov și voiu adăvăsi în Izdrail" ['I will divide them in Jacob, and scatter them in Israel'] (Gen, 49, 7). From this general meaning 'to waste', the adjective adăvăsit derived its meaning 'scattered, spent, exhausted', with which it appears in a note in GB $\left(271^{\mathrm{v}} / 1\right)$, where it corresponds to Slav. dospéti 'tired, weary' (see also Pamfil, 1958, p. 234). With a similar meaning, designating 'to (be) overwork(ed), to consume, to (be) exhaust(ed)', it can be found in the next century with a distribution in northern Transylvania and in Moldavia (cf. DLRLV, s.v., where see also the variant adevăsi). From the semantic nucleus 'to waste (one's wealth)' it could be developed the meaning 'to spend, to perish', attested in Moldavia (cf. DA, s.v.). With this latter meaning, the term is employed nowadays in some regions of Transylvania and in Oltenia (Pamfil, 1958, p. 234). The more or less distinct meanings ${ }^{5}$, with which the term is registered in Transylvania, have a common denotation 'to cease, permanently or temporarily, to exist in the original form, whether it refers to living things - 'to (be) scattered (about people), to (be) destroy(ed), to disappear' - or to material goods - 'to dispel, to consume, to spend, to waste', etc. In all these cases, the change of a state of facts leads to a deficient situation, which results in a loss, a disadvantage. In contrast with these nuances found in Hungarian too, Romanian language developed an opposite meaning to the initial one, namely 'to gather, to collect', noted in Iași (Lex. reg., I, 63); and also adevesesc 'to bargain', found in Vaslui (cf. Gheție \& Mareș, 1974, p. 263).

4.3. As mentioned before, lexical meaning is probably the most charged with thought (Gafton, 2010, p. 84) and, in the same time, with affectivity. Lexical items reflect the way in which the world is conceptualised, the way in which people relate to it and, at the same time, they are imbued with sensitivity, with the emotional experiences which characterise a linguistic community and which are assumed by the speakers of the language, either willingly or unconsciously by the fact that they belong to a particular ethnic group and language. In other words, lexemes function as vehicles for storing emotional, volitional predispositions characteristic for a community, as linguistic "exponents" of its spiritual universe. It should also be noted that the lexical meaning and the phonetic pattern, due to its sonority, often converge, bearing the same emotional and spiritual content. This fact explains, to a certain extent, those semantic changes occurred within the target language which appear to be unmotivated or, in any event, less justified linguistically. In these cases, the semantic changes are the most spectacular and interesting since the emotional universe is rarely taken over along with the loanword. Under these circumstances, it is only natural to adapt the emotional content of the word to the sensitivity and spirituality of the speakers who borrowed it.

An eloquent example of those stated above is the situation of Rom. bănat (< Hung. banat 'sorrow, lamentation, pain, regret'; cf. Mândrescu, 1892, p. 134-135; cf. EWUR, p. 99-100; cf. DER, s.v.). In the sixteenth century, this term is attested with the meanings 'grief, sorrow, pain, disgust', 'sadness, misery, regret, trouble', recorded in $\mathrm{PH}$, with numerous occurrences: "Bănat și lî̀ $<\mathrm{n}>$ goare aflaiu” ['I found trouble and sorrow'] $\left(100^{\mathrm{r}} / 3\right)$, “Bănat și nevoi aflară-me” ['Trouble and anguish have taken hold on me'] (108 r 143), “bănatulu e aproape, că nu e cinre se-mi agiute” ['trouble is near; for there is none to help'] (17 $/ 12)$, "Multe bănaturi derepților și de toate-i va izbăvi ei Domnulu" ['Many are the afflictions of the righteous: but the Lord delivereth him out of them all'] $\left(28^{\mathrm{r}} / 20\right)$, in phrases like: intru bănatu $\left(2^{\mathrm{v}} / 2\right)$, de tot bănatul $\left(20^{\mathrm{v}} / 22\right)$, de la toate bănaturile $\left(27^{\mathrm{v}} / 5\right)$, în vremea bănatului (32 $\left./ 39\right)$, in mijloc de bănat $\left(117^{\mathrm{r}} / 7\right)$.

It is interesting how the term has broadened its semantic sphere from the nucleus meaning 'regret, melancholy', also found in Hungarian, to the nuances 'longing, anger, grief', 'grudge, reprimand', attested in Romanian language. The explanation must be sought, we believe, in the different spirituality of Romanians and Hungarians. Thus, for instance, it may be noticed that Hungarian people are characterised by

\footnotetext{
${ }^{5}$ With the meaning 'to scatter, to destroy' in Alba; 'to disappear' in Bistrița-Năsăud, where see also the variant adevesi 'to lose' (Lex. reg., II, 75); a dăvăsi 'to lose (or be lost)' in Maramureș; a devăsi 'to (be) scatter(ed), to lose, to deteriorate' in j. Sibiu (Lex. reg., II, 59); a devesi 'to go to waste, to lavish' in j. Brașov; a tăvăsi 'to perish' in the Apuseni Mountains (cf. Gheție \& Mareș, 1974, p. 263).
} 
a predisposition to lament, melancholy, by a world view which is often painted in serious, gloomy tones. This sensibility is reflected par excellence in the Hungarian word bánat (< vb. bán-ni 'to regret (mainly one's own actions)' + noun suffix - at) which, by its lexical meaning of 'sorrow, grief, regret', circumscribes a meditative universe perfused with sobriety. The phonetic pattern, in its turn, sustains the serious tone, by alternating the $[a]-[a]$, vowel pair imposed by vowel harmony. This latter aspect is not fructified in the Romanian loanword, since Romanian language lacks vowel harmony which governs the distinction between back vs. front vowels.

The conceptual domain of the Hungarian noun seems to circumscribe a state of mind characterised by helplessness, partly found in the meanings of the Romanian term too. Beside this nuance, the meaning of the Hungarian term also includes an ethical-moral and religious dimension, bánat denoting 'sorrow, regret, guiltiness felt by a believer because of his sins, repentance' (Czuczor \& Fogarasi, s.v.). This nuance refers to self-examination which assumes the internalisation of the experiences. This meaning is not entirely unfamiliar to the Romanian loanword either, being found especially in bilingual's speech in regions strongly influenced by Hungarians. Thus, bănat has been registered, ever since the sixteenth century, with the meanings 'sorrow, grief, regret', with a distribution in Banat-Hunedoara. These meanings are preserved in the next century as well in Moldavia, in Crișana, in southwest and northern Transylvania (cf. DLRLV, s.v.). Nevertheless, the nuance 'repentance' seems to be placed on a peripheral position compared to the other meanings developed independently of the etymon. This might be sustained by the fact that Rom. bănat is often used with meanings which point to an externalised emotion, to the projection of the idea of 'guilt' on to the outside world. Such a direction seem to circumscribe meanings like 'rancour, envy', 'suspicion' (DER); 'anger, grudge', 'suspicion, distrust' (SD, s.v.); 'grief, anger', 'wrath, trouble, vexation', 'blame, reproach, reprimand, scolding, 'hunch, suspicion' (cf. DLRLV, s.v.), registered in different Romanian dictionaries. Whatever the case, the coexistence of the nuances 'reflection on the self' and 'projection on to the other', present in the Romanian word ${ }^{6}$, seems rather curious.

4.4. Derived from the same root as the previous term, in the same category might be analysed the Romanian word a bănui (Romanian derivative < Hung. bán-ni 'to regret' + -ui; cf. Mândrescu, 1892, p. 136-137; cf. EWUR, p. 100-101). The loanword shows a spectacular semantic development within Romanian language, widening its semantic sphere with meanings which are not found in the Hungarian etymon. Thus, the Romanian verb is used in old Romanian psalms with the etymological meaning 'to repent, to regret,' 'to mourn, to be distressed', recorded, for instance, in PH: "Cătră Domnul cîndu bănuiiu chemaiu și me audzi” ['In my distress I cried unto the Lord, and he heard me'] (109/1), "Nu întoarce fața ta de la fătul tău, / că bănuiescu; curru $<\mathrm{n}>\mathrm{du}$ a $<\mathrm{u}>\mathrm{dzi}$ me" ['And hide not thy face from thy servant; for I am in trouble: hear me speedily'] (58\% /18), "așteptaiu cinre e se bănuiască și nu fu” ['and I looked (...) for comforters, but I found none'] (58v/21), "În porîncitele tale bănuiiu și înțeleșu caile tale” ['I will meditate in thy precepts, and have respect unto thy ways'] $\left(102^{\mathrm{v}} / 15\right)$. The primary meaning 'to sorrow, to repent, to regret' is preserved in the seventeenth century too, its distribution including Moldavia, Banat, Crișana and southwest Transylvania (cf. DLRLV, s.v.) and it is still in use in certain Transylvanian regions (cf. ILR I, p. 242). The semantic nucleus 'regret' covers a range of different nuances, including 'to worry, to sorrow, to pain' ( $\left.\mathrm{PH}, 58^{\mathrm{v}} / 18,21\right)$, 'to be painstaking, to show special care to do something' $\left(\mathrm{PH}, 102^{\mathrm{v}} / 15\right)$, also found in Hungarian. Within Romanian language, however, its semantic sphere has been widened, embracing the nuance 'to lament', expressing the idea of 'discontent' which could led to the development of new meanings. Thus, in the seventeenth century, the term is recorded with the meaning 'to take (something) amiss, to anger, to displease, to outrage', in Moldavia and in Muntenia, whereas in southwest Transylvania and in Muntenia the meaning 'to suspect' is (also) attested. The term is recorded, in this century, with the figurative meanings 'to murmur (against)' (in Moldavia) and 'to envy, to begrudge' (in Muntenia) (cf. DLRLV, s.v.). Nowadays Rom. a bănui registers, beside its regional usage 'to regret' (CADE, s.v.), other

\footnotetext{
${ }^{6}$ Among the synonyms of bănat, dictionaries register the following: amărăciune, întristare, tristețe, necaz; mîhnire, supărare, dar și admonestare, ceartă, certare, dojană, dojenire, mustrare; ciudă, gelozie, invidie; neîncredere, bănuială, suspiciune; învinuire, imputare; pică, pizmă, pornire, ranchiună, reproș; vină.
} 
meanings as well, like 'to submit claims', and 'to (be) offend(ed), to (be) insult(ed)' (DER, s.v.). Used as a transitive verb, it developed the meaning 'to nurture bad feelings/opinion; to reproach, to scold', which explains its current meaning 'to think unfavourably of someone'. Therefore, despite the fact that between the etymological meaning 'to regret' and its derived meanings 'to suspect, to question', 'to assume a person or action as guilty or reproachable' there is quite a distance, these meanings are not completly unrelated'.

4.5. Another term within the word family of the Hungarian verb bán-ni 'to be troubled, to regret' is its factitive form, bánt-(a)ni 'to cause pain, to hurt, to harm someone' (cf. MESz, s.v.), from which the Romanian verb a bîntui derives (cf. Mândrescu, 1892, p. 136; cf. EWUR, p. 126; cf. DER, s.v.). The Romanian word either has been explained by multiple etymology, being also found in the Slavonic languages (see bantovati), or it has been introduced in the series of verbs with -ui ending and explained by Slavonic mediation. Romanians in contact with both languages, however, may have borrowed this word either from one or the other, or even from both of these languages, depending on the different regions of the country or even repeatedly, at different times (cf. Arvinte \& Gafton, 2007, p. 97). In areas of direct contact with the Hungarian population, it would not be wrong to assume that Romanians have borrowed the word from the Hungarians. As for its phonetic treatment, Hung. [á] first changed into Rom. [ă], according to the articulatory practice of Romanian language and then it became $[\hat{\imath}]$ "since before $[n]+$ consonant it has been more familiar" this latter one (Király, 1990, p. 118) ${ }^{8}$. Finally, the suffix $-u i$ has been added to it within Romanian language (cf. a făgădui, a tăgădui, etc.).

The more or less distinct nuances included within the conceptual domain of the verb a bintui revolve around the central idea 'to hurt, to harm' evoking, thus, undesirable effects, damages. As a matter of fact, this is the semantic nucleus of the Hungarian etymon bant-a-ni, which contains the correlated nuances 'to hurt, to offend, to annoy, to disrupt (someone or something)', '(referring to natural phenomena) to cause damages' or '(about diseases) to torment' (cf. Czuczor \& Fogarasi, s.v.). The term is attested in the sixteenth century with its etymological meaning 'to harm, to hurt', recorded in documents from all three Romanian principalities: "nime să nu-l bîntuiască preste cartea mea" ['no one shall harm him above my deeds'] (Dî,, XLI, 5, *Trans.), "ne-au băntuit în slujba noastră” ['they hurt us in our service'] (Dî, XLIV, $237^{\mathrm{V}} / 8,{ }^{*}$ Mold.), "nime să n-aibă $\boldsymbol{a}$-i bîntui preste dzisa noastră” ['no one shall harm them above our word'] (Dî, CX, 8), where see also der. bîntuială 'harm, mischief': "și de nimea bîntuială să nu aib[ă] niciodată”

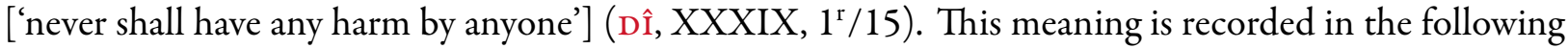
centuries as well.

Although sporadically, old Romanian language records meanings closest to the current usage too, for instance, the meaning 'to throw oneself upon something' ( $\left.\mathrm{CC}_{1}, 172\right)$ (cf. ILR II, p. 269). The current Romanian usages seem to insist on the intensity of the damages done, the word acquiring the meaning '(about forces of nature) to hit insistently and violently', '(about diseases, wars, invasions) to ravage, to devastate, to wreak havoc', '(about living things) to oppress, to subjugate'. Regionally, the word appears in imprecations too: $S \breve{a}$ (mă) bintuie (Dumnezeu) 'to punish, to strike (me) (God)' (cf. DEx, '98, s.v.). As it can be noticed, unlike the more delicate connotations in Hungarian, where the verb expresses, in most contexts, merely 'trouble, annoyance' (cf. sérelem, szomorúság, Czuczor \& Fogarasi, s.v.), the Romanian language has developed its more intense nuance 'devastation', by exacerbating the virtual valencies contained in the etymon. The meanings '(about spirits) to roam,' 'to torment, to haunt' and 'to tempt' have also developed within Romanian (cf. CADE, s.v.).

4.6. Another case taken into account is that of Rom. gind (< Hung. gond 1. 'cura,' 'sorge', 2. 'cogitatio', MNYSZ; cf. EWUR, p. 386; cf. DER, s.v.), quite widely employed in old Romanian'. Although rarely,

\footnotetext{
${ }^{7}$ The negative nuance 'to despise' may already be noticed in $\mathrm{PH}\left(58^{\mathrm{v}} / 18\right)$ (cf. Rosetti, 1931, p. 147).

${ }^{8}$ The same transition from $[\breve{a}]$ to $[\hat{\imath}]$ takes place in Rom. întîlni 'to meet' < (în)tălni < Hung. találni 'to find, to meet', as well as in the case of the transformation of the unstressed $[e]$ in nasal position (cf. Hung. menteni > Rom. măntui > mîntui 'to save, to redeem'), which is present, in fact, in the case of all the inherited words in Romanian.

${ }^{9}$ In old Romanian texts which contain translations of the Old Testament, there is no "unitary individual lexical norm", common for all translators, for the notion 'conscience'. In each text we may notice, however, a tendency towards establishing
} 
in literature, it has been proposed for Hung. gond > Rom. gind the hypothesis of Slavonic mediation (see Pușcariu, 1940, p. 299). In this case, such a mediation, though possible, is not necessary since the Romanian form could perfectly be explained by the Hungarian etymon, if we take into account the principles of the Hungarian loanwords' phonetic adaptation. Thus, for the transition of $[o]$ to $[\hat{\imath}]$, in this word, Slavonic mediation is not the only possible solution since in Romanian $[o]+[n, \mathrm{~m} \mathrm{l} . \mathrm{r}]+$ an other consonant $>[\breve{a}]>[\hat{\imath}]$ also occurs in other words in which Slavonic languages did not play any role.

Concerning the semantic changes of this term, it may be noticed that between the meaning of its etymon gond and the old and new meanings of the loanword gind there is quite a large distance (cf. also ILR I, p. 242 $)^{10}$. In Hungarian, the noun denotes 'a troubled conscience', 'a conscience characterised by uneasiness', associating, thus, the intellect with emotions (cf. bizonyos nyugtalansággal és kedvetlen érzéssel, aggálylyal párosúl, Czuczor \& Fogarasi, s.v.). All the other meanings of gond-see 'carefulness' or 'precision, exigency' (cf. MESz, s.v.) - bear, in fact, an emotional connotation. In contrast to this state of affairs, gind entered Romanian language carrying a neutral affective value denoting 'thought, mind, conscience'. Thus, in CV it is recorded the meaning 'conscience, thought" ${ }^{\text {'1 }}$ "Bărrbați frați, eu cu totu gindul cela bunrul viu" ['Men and brethren, I have come in all good conscience'] (23\%/2-4), "nevinovatu gîndu aibîndu" ['having pure conscience'] (31 $/ 6-7)$, “cu gîndurele cealea bunrele” ['with all good conscience'] $\left(78^{\mathrm{v}} / 12-13\right)$; with the meaning 'thought' it appears in Св: "curatului gîndu" ['pure thought'] $(2 P, 3,1)$; and in documents: "acel svat și acel gîndu" ['that counsel and thought'] (Dî, XCIII, 1 ${ }^{\mathrm{r}} / 6$ ), where see also the var. ghendul (Dî, C, 82 $/ 11$ ). This meaning, although found in the word gond (cf. MNYSz, s.v.), renders rather the semantic nucleus of the Hungarian derivative gondolat. Romanian language developed then other meanings too, such as: 'wisdom', recorded in PH: "ciudele tale, și cu gîndurile tale nu e cinre se va asăm<ă $>$ na ție" ['thy acts and thy wisdom there is no one to resemble thou'] (34 $\left.4^{\mathrm{r}} / 6\right)$; 'foresight, wisdom' in CV: "Multă lume nemereaște cu tinre și isprăvire easte limbiei aceștiia cu ale tale gîndure" $\left.\left(29^{\mathrm{r}} / 7-11\right)^{12}\right)$; 'intention' in PH: "tu înțeleseși gîndul mieu de departe" ['thou understand my intent'] $\left(117^{\mathrm{v}} / 3\right)$, cf. also in phrases like: a umbla cu gîndul: "în casa Dzeului îmblăm cu <gî $>n d u l$ " ['we walk with intent in the house of God'] (46r/15), in Cs: "ceia ce poartă gîndu bunu" ['those who nurture good intent'] (V, 51 $/ 17)$, as well as in documents, especially from Transylvania and Moldavia: "gîndul și voia gărdinarului" ['the intent and will of the gardener'] (Dî, XXXVI, 249v/10, Trans.), "i-au fost gîndul cum mă va piiarde" ['he intended to make me perish'] (Dî, XLIV, 237 /12, Mold.); 'ostentation, pomp', 'imagination,' 'deception' in CV: "Venre Agripa și Vernichie cu multu gîndu" $\left(36^{\mathrm{r}} / 4\right)^{13}$. The Romanian term also denotes the meaning 'carefulness, worry, suspicion, intent' (cf. Niculescu, 2005, p. 120). Its current usages have widened the semantic sphere of the word, gind designating 'idea', 'meditation, reflection', 'opinion, belief', 'spirit, intelligence' (cf. DER, s.v.).

4.7. The intensification of a semantic nuance virtually included in the etymon appears quite in a particular manner in the case of Rom. a fägădui (Rom. der. < Hung. fogad-ni 'to receive, to accept, to host', and 'to promise, to entrust', especially with the verbal preffix meg-fogad, + -ui; cf. Mândrescu, 1892, p. 151-153; cf. EWUR, p. 319; cf. DER, s.v.), which occupies a significant position among the old Hungarian loanwords, in terms of its frequency, semantic diversity, variety of inflected forms and derivatives.

The Hungarian verb fogad-ni includes many nuances within its conceptual domain which revolve around two semantic nuclei: 1. 'to receive (someone as guest)', also implying a certain 'kindness, hospitality' (cf. bizonyos kedvvel, kedélylyel lát, Czuczor \& Fogarasi, s.v.), and 2. 'to promise, to engage oneself in

\footnotetext{
such a norm. Thus, in Coresi's texts, for instance, just like in CV, whenever the notion 'conscience' appears in the Slavonic source text, it is generally translated with the word gind (Munteanu, 2008, p. 370).

${ }^{10}$ The author notices the semantic difference between gond 'concern' and gind 'thought, idea' and he remarks that the Hungarian word also has the meaning 'thought', recorded in Hungarian dictionaries (especially in the form gondolat).

${ }^{11}$ Corresponding to sfeat(uri) in Coresi's text.

${ }^{12}$ Cf. cugetat in Coresi's text.

${ }^{13}$ In Coresi's text, see amegire. In other passages of the text, the words cugetat $\left(29^{\mathrm{r}} / 7-11\right)$ or sfeat $\left(23^{\mathrm{v}} / 2-4\right)$ are used.
} 
the fulfillment of a promise'. In Romanian, the loanword a fägădui does not preserve all the meanings of its etymon, which is not at all unusual. What is interesting, however, is that, although both semantic centres are preserved in Romanian too, their rank is reversed in the target language. Thus, in the contemporary Romanian language, the customary (normative) meaning of the verb, with which it is employed almost exclusively, belongs to the semantic sphere 'to promise' whereas 'to host (someone as guest)' became an occasional ${ }^{14}$ meaning, employed especially regionally.

The term is recorded in old Romanian texts particularly nuanced. Thus, the etymological meaning 'to receive (someone as guest)' is registered in CV: 'Și deca fumu noi întru Ierusalim, cu iuboste făgăduiră noi frații" ['Being in Jerusalem our brethren received us with kindness'] $\left(14^{\mathrm{v}} / 14-15^{\mathrm{r}} / 1-2\right)$; other etymological meanings are: 'to host, to accommodate' in CS: "de se nu-l fägăduimu elu" ['so we do not host him'] (XV, 122\%/6), and 'to receive, to accept' in Ps: "Audi Doamne dereptate me, făgăduiaște rugăciure me" ['Hear, my Lord, my righteousness and receive my prayer'] $(16,1)$. The specific nuances of 'benevolence, cordiality' associated with the etymological meaning facilitated the development of other nuances, such as 'obedience', from which it could derive the meaning 'to listen to someone, to take the advice', recorded in PO: "Și frații lui luară și făgăduiră lui cuvîntul" ['And his brethren listened and took his advice'] (Gen, 37, 27). As a matter of fact, the Hungarian verb, in its turn, includes among its meanings the distinctive nuance 'successfully and fruitfully receive/accept' (cf. valamit sikeresen, gyümölcsözöleg vesz magába, Czuczor \& Fogarasi, s.v.). In Romanian, however, the applicability of this fruitful acquiescence extends only to internalizing 'the word of someone', unlike Hungarian usages in which, beside 'obedience (to what others say)' (cf. the Hung. phrase szót fogadni), it also includes the idea of 'fertility', in other words, 'to (fruitfully) receive a fetus within the womb' (cf. gyermeket mébbe fogadni, Czuczor \& Fogarasi, s.v.). It is interesting that this nuance, although frequently employed in the Hungarian version of PO (see fogada és szüle '(she) conceived and bare'), is not preserved in Romanian. This nuance is repeatedly expressed by another loanword, likewise of Hungarian origin: fu tăroasă (Gen, 4, 1). In the same semantic sphere could be included the derived meaning 'to take as husband/wife' in $\mathrm{CB}$ : "se făgăduiască soț pre soțu" ( $F A, 19$, $38)$.

Taking into account the other semantic nucleus of 'commitment', it has, in its turn, different degrees of intensity in old Romanian texts. The verb denotes 'to promise' in FRAG.TOD.: "făgăduit-ai noauă că ne vei slobodzi" ['thou promised to free us'] ( $\left.4^{\mathrm{r}} / 27\right)$, as well as in PO: "cum Domnul lu Avraam să dea cea au făgăduit lui" ['that the Lord may bring upon Abraham that which he hath spoken of him'] (Gen, 18, 19) ${ }^{15}$; with the meaning 'to promise, to swear' it appears in PH: "Că se giură / Domnului <și > făgădui-se lu Dumnedzeu" ['promised and sweareth to God'] $\left(113^{\mathrm{v}} / 2\right)$, in Св: "și faggădui să dea lui" ['promised to give him'] $(F A, 7,5)^{16}$, etc. In other passages, the term designates commitment made to divinity, as in $\mathrm{Cs}$, where the reflexive form ${ }^{17}$ is employed with the meaning 'to pray, to swear allegiance': "Acesta sintu cei ce s-au botedzat și se-au fägăduitu cruciei" ['these are the baptised and who swore allegiance to the cross'] (IV, $\left.31^{\mathrm{r}} / 12\right)$.

The loanword shows an extraordinary vitality, developing numerous derivatives, such as: noun faggăduit in PS.C.: "pus'ai lacrîmele mele între tine, că în făgîduitulŭ tău" ['put my tears in thou and thy promise'] (55/15); adj. făgăduit 'promised' in $\mathrm{CC}_{2}$ : "pămîntului făgăduit" ['promised land'] (7/5-6); noun făgăduită 'promise' in PH: "pus-ai lacrămile meale între tinre ca în făgăduita ta” (47 $/ 9$ ); fägăduită

\footnotetext{
${ }^{14}$ As a matter of fact, it has been proposed the possibility that the two meanings could belong to a homonymous pair of words: 1. a fagăadui 'to receive (as a guest)', and 2. a făgădui 'to promise' (cf. Graur, 1954, p. 127). Although the relation between the two meanings is perhaps more difficult to establish, the distance between them is not insurmountable. Therefore, we believe that the two semantic nuclei should not be regarded as belonging to two different words, but rather as nuances of the same term, since both may be found in the sixteenth century.

${ }^{15}$ In the Hungarian version we encounter the corresponding words igirte, igiret 'promise'.

${ }^{16}$ Its presence with the given meaning shows a deliberate choice of the author for this term since in Romanian language there existed other synonyms too which appear in other versions of the same passage, see a giurui (CV), a jura (CP).

${ }^{17}$ The initially transitive verb became reflexive in Romanian language by analogy with other verbs (cf. a se apuca, a se angaja) with the meaning 'to promise' (Mândrescu, 1892, p. 151-152).
} 
'promise, pledge' in Св: "să nu împarță-se, ce ca așteapte făgăduita Tatălui" ['to wait there for what the Father had promised'] $(F A, 1,4)^{18}$, where see also the var. fägădoita (Fap, 2, 33); noun fägăduitură 'promise, vow' in CAT.C.: "că toate făgăduiturile lui Dumnezeu cu credință numai să le putem cuprinde la noi" ['we shall embrace with faith all of Lord's promises'] $\left(10^{\mathrm{r}} / 1-5\right)$ and in CS (XII, 105 $\left./ 16-105^{\mathrm{v}} / 4\right)$; fägăduire(a) in СВ: "ceia ce părințiiloru-ne făgăduirea ce fost-au" ['the promise made to our ancestors'] $(F A, 13,32)$; noun der. fägăduială: "porunca împăratului și făgăduiala ce ne-au fost trimese" ['the command of the emperor and the promise sent to us'] (Dî, XXXI, 253\% $/ 10$ ). The term forms compounds too, such as: bun(r)ă-făgăduită in CV: "a rădica cumîndare Duhului bunră-făgăduită Dzeului Isus Hristos" (73/9$11)$ and in Св: "bună-făgăduitele lu Dumnezeu" $(1 P, 2,5)$. For other derivatives see CADE, SD.

As shown above, in the sixteenth century, the term has a wide usage, its distribution including especially north- and south-western Transylvania. In the following century, its meaning 'to receive, to take into consideration' has a diffusion in south-western Transylvania; noun der. fagăduială 'promise' in Muntenia and the noun der. fägadă 'reception, acceptance' and 'promise' in Moldavia (cf. DLRLV, s.v.). Thus, the loanword of Hungarian origin most likely complied with the common linguistic norm of the sixteenth century. It has also been preserved in the contemporary literary language (especially with the meaning 'to promise'), which may be partially due to the fact that it had been recorded in biblical texts, carrying, thus, some sort of sacredness and a tradition which could not be replaced, although the term has been competed with its neological synonyms (see Rom. a promite $<$ French).

4.8. The diversification of the meanings acquired within Romanian language appears to be quite noteworthy in the case of Rom. a (se) tămădui (Rom. der. < Hung. támad-ni 'oborior, exsurgo'; 'entspringen, aufstehen', MNYSZ, + -ui; cf. Mândrescu, 1892, p. 185; cf. EWUR, p. 769-770; cf. DER, s.v.), which has developed a conceptual domain different from that of its etymon. Notwithstanding that the transition from one meaning to the other may seem rather difficult to explain, the breach between the meanings of the Hungarian verb and those of the Romanian loanword is, in fact, only apparent.

The primary meaning of Hung. támad-ni is 'to elevate, to rise' from which it could have derived its current meaning 'to rise against (someone), to revolt'. In old Romanian language, the loanword is recorded with the meaning 'to (be) heal(ed), to (be) cure(d), to recover', also found in its noun derivative tămăduire: "Se fie iarba la tămăduire, aceaea ainte de covrag și secă” (PH, 112 /6), adj. tămăduit: "<Și > oameri tămăduiți lăuda-vor Domnulu” ( $\mathrm{pH}, 84^{\mathrm{r}} / 19$ ), which could be a continuation of its etymological meaning, by adding the nuance 'to rise from a disease ${ }^{\text {'19 }}$. It is somewhat more difficult to explain the meaning 'to create' with which it is recorded in PH: "Înrimă curată tă/măduiaşte întru menre" ['Create in me a clean heart'] (43\% / 12), "Trimite-veri aburul lor și se vor tămădui" ['Thou sendest forth thy spirit, they are created'] $\left(87^{\mathrm{v}} / 30\right)^{20}$. This seems to reproduce the etymological meaning 'to arise, to be born' (cf. ered, keltezik, Czuczor \& Fogarasi, s.v.), with which it could have been spread in certain regions, though we have no attestation of this usage. In the sixteenth century, the term is also recorded with the meaning 'to build"21 in PH: "Și se tămăduiască-se păreții" ['build thou the walls'] (43"20), and in CP: "Rugă ei cum să se tămăduiască și să lăcuiască în pridădirea credințeei” (Sp. la Iuda) ${ }^{22}$, which may continue the broadened semantic sphere of the Hungarian word 'to assist (in rising)' (cf. felemelkedve megtámogat, alátámaszt jelentéskör, $\mathrm{MESz}$, s.v.).

In the contemporary Romanian language, the contexts in which the loanword is used include the idea 'disease'. Thus, in its transitive and reflexive usages, the customary meaning 'to (be) heal(ed), to (be)

\footnotetext{
${ }^{18}$ The noun fägăduită 'pledge' also appears in $\mathrm{CC}_{2}$ (cf. INDICE XVI, p. 154).

${ }^{19}$ Among the numerous meanings of Hung. támadni, the one which is closest to that of Rom. tămădui is 'to rise', from which the Romanian meaning 'to rise from a disease, to recover' could have derived (Mândrescu, 1892, p. 185). In a similar manner, O. Densusianu (in ILR I, p. 242) notices that "Hung. támadni 'to appear, to rise' = Rom. tămăduire 'to be convalescent, to heal, to recover"”.

${ }^{20}$ See creabantur in Vulgata, cf. ILR II, p. 307.

${ }^{21}$ Cf. also Studiu lingvistic to PH, p. 66.

${ }^{22}$ Corresponding to nevoiască-se recorded in $\mathrm{CB}$.
} 
cure(d)' (cf. DER, s.v.) has several nuances, such as: 'to straighten up, to return to the normal state (after an illness),' '(about an injury) to disappear after treatment', '(about oppressive moods) to cease to manifest' (cf. NODEX, s.v.). The last two meanings ('to disappear', 'to cease') even contradict the etymological meaning which, on the contrary, implies a 'starting point'. Related to the idea 'to disappear' we may also discuss the meanings recorded in different dictionaries: 'to steal' (cf. SD, s.v.) and 'to escape' (cf. CADE, s.v.), explicable by extension. Its noun derivatives tămăduială, tămăduire preserve the old semantic nuance 'healing, cure', while the noun tămăduitor 'healer' is registered in religious texts with the figurative meaning 'the Saviour (Jesus) ${ }^{23}$ too. This latter meaning may be explained within the context of the Easter festival, since the Hungarian term (fel)-támad-(ás) also means 'resurrection, rising (of Christ)', developing hence the primary meaning 'to rise' (from the dead).

\section{Conclusions}

Hungarian lexical borrowings appear as a natural product of the cohabitation of the two lingustic communities. These had quite a remarcable impact on Romanian vocabulary, determining its structure even beyond the period of direct contacts. The more tight and varied the interethnic relations were, especially in certain regions of the country, the more intensely entagled became the two linguistic systems and, implicitly, the two universes of thought, each of them responding to this contact situation in a different way. The reactions manifested by the target language to this linguistic and cultural "conflict" situation produced by contacts between the two nations may be analysed, in quite a particular manner, through the semantic changes of loanwords. These are quite edifying for the study of linguistic contacts since, as shown above, the changes occured in the signified bring to light not only the mechanisms characteristic for the operations of the target language, but also those involved in the interaction between the two languages. Thus, beside the phonetic and morpho-syntactic levels, perhaps the most profound consequences of linguistic contacts may be found on the level of signification. This should be analysed in its evolution, diachronic approach being the most efficient, if not the only way to describe the consequences of interethnic and linguistic contacts consistent with linguistic reality, since the mere description of a certain phenomenon in a given stage of the (Romanian) language does not solve much about the issue, its deep understanding coming from the diachronic apprehension of the emergence, development and evolution of all the things that subsequently led to the existence of that very phenomenon.

\section{Bibliography}

\section{A. Text editions}

$\mathrm{CC}_{1}=$ Coresi, Cazania I, cca 1567; ed. Vl. Drimba, București, Editura Academiei Române, 1998.

$\mathrm{CC}_{2}=$ Coresi, Cazania a II-a, Brașov, 1581; ed. S. Pușcariu și A. Procopovici, București, 1914.

CAT.C. = Coresi, Catehismul, text stabilit, studiu filologic, studiu lingvistic și indice de A. Roman-Moraru, în TEXTE ROM., p. 19-128.

Св = Codicele Bratul, ediție de text de Al. Gafton, Editura Universității „Alexandru Ioan Cuza”, Iași, 2003.

$\mathrm{CP}=$ Texte de limbă din secolul XVI reproduse în facsimile îngrijite de I. Bianu, membru al Academiei Române. IV. Lucrul

Apostolesc. Apostolul tipărit de diaconul Coresi la Brașov în anul 1563, București, 1930.

Cs = Codex Sturdzanus, studiu filologic, studiu lingvistic, ediție de text și indice de cuvinte de Gh. Chivu, București, 1993.

$\mathrm{CV}=$ Codicele Voronețean, ediție critică, studiu filologic și studiu lingvistic de M. Costinescu, Editura Minerva, București, 1981.

Dî = Documente și însemnări românești din secolul al XVI-lea, text stabilit și indice de Gh. Chivu, M. Georgescu, M. Ioniță, Al.

Mareș și A. Roman-Moraru, cu o Introducere de Al. Mareș, București, 1979.

FRAG.TOD. = Fragmentul Todorescu, text stabilit, studiu filologic, studiu lingvistic și indice de I. Gheție, în TEXTE ROM., p. 259-364.

GB = Glosele Bogdan, text stabilit, studiu filologic, studiu lingvistic și indice de M. Georgescu, în TEXTE ROM., p. $365-463$. PH = Psaltirea Hurmuzaki, I. Studiu filologic, studiu lingvistic și ediție de I. Gheție și M. Teodorescu, II. Indice de cuvinte de

Rovena Șenchi, București, 2005.

23“Căci el este tămăduitorul sufletelor rănite” ["For he is the bealer of our souls”] (Mândrescu, 1892, p. 185). 
PO = Palia de la Orăștie (1582), I. Textul, Text stabilit și îngrijire editorială de V. Arvinte, I. Caproșu și Al. Gafton, Editura Universităţii „Alexandru Ioan Cuza”, Iași, 2005.

PS = Psaltirea scheiană comparată cu celelalte Psaltiri din sec. XVI și XVII traduse din slavonește, edițiune critică de I.-A. Candrea, București, 1916.

PS.C. = Psaltirea publicată românesce la 1577 de diaconulu Coresi, reprodusă cu unu studiu bibliograficu și unu glosaru comparativu de B. Petriceicu Hasdeu, edițiunea Academiei Române, tomulu I, textulu, Bucuresci, 1881.

TeXTe Rom. = Texte românești din secolul al XVI-lea. I. Catehismul lui Coresi. II. Pravila lui Coresi. III. Fragmentul Todorescu. IV. Glosele Bogdan. V. Prefẹ̦e și epiloguri, de Gheție, I. (coord.), Editura Academiei, București, 1982.

\section{B. Dictionaries}

CADE = Candrea, I.-A. \& Adamescu, Gh., Dicționar enciclopedic ilustrat, Editura „Cartea Românească,” București, 1931.

Czuczor G. \& Fogarasi J. (1862-1874). A magyar nyelv szótára, I-VI, Pest.

DA = Dicționarul limbii române, București, 1913-1949.

DER = Ciorănescu, Al., Dicționarul etimologic al limbii române, ediție îngrijită și traducere din limba spaniolă, de T. Șandru

Mehedinți și M. Popescu Marin, Editura Saeculum I. O., București, 2002.

DEX = Dictionarul explicativ al limbii române.

DLRLV = Costinescu M., Georgescu M. \& Zgraon F., Dicționarul limbii române literare vechi (1640-1780). Termeni regionali,

București, Editura Științifică și Enciclopedică, 1987.

EWUR = Lajos, T., Etymologisch-historisches Wörterbuch der ungarischen Elemente im rumänischen, Budapest, 1966.

INDICE XVI = F. Dimitrescu et al., Indice lexical paralel. Secolul al XVI-lea, în Dimitrescu, F., Contribuții la istoria limbii române vechi, Editura Didactică și Pedagogică, București, 1973, p. 122-245.

Lex. reg. = Lexic regional, coord. Gh. Bulgăr, vol. I, București, Editura Academiei, 1960, vol. II, [București], 1967.

$\mathrm{MESz}=$ Tótfalusi, I., Magyar etimológiai nagyszótár.

MNYSz = Szarvas, G. \& Simonyi, Zs., Magyar nyelvtörténeti szótár, I-III, Budapest, 1890, 1891, 1893.

NODEX $=$ Noul dicționar explicative al limbii române.

SD = Scriban, A., Dicționaru limbii românești, Iași, 1939.

TRDW = Tiktin, H., Rumänisch-Deutsches Wörterbuch, Wiesbaden, (cu etimologii revăzute de Vasile Arvinte), 1985.

\section{Scientific journals}

$\mathrm{CL}=$ „Cercetări de lingvistică”, Cluj.

$\mathrm{DR}=$ „Dacoromania”, Buletinul Muzeului limbii române, Cluj.

MNY = „Magyar Nyelv”, ed. Szily Kálmán, Melich János, Magyar Nyelvtudományi Társaság, Budapest, 1920.

MNYR = „Magyar Nyelvőr”, ed. Simonyi Zsigmond, Magyar Tudományos Akadémia, Budapest 1898.

\section{References}

Arvinte, V. \& Gafton, Al. (2007). Palia de la Orăștie (1582). II. Studii, Editura Universității „Alexandru Ioan Cuza,” Iași. Bally, Ch. (1926). Le langage et la vie, Payot, Paris.

Bréal, M. (1897). Essai de sémantique (science des significations), Hachette, Paris.

Humboldt, W. v. (1836/2008). Über die Verschiedenheit des menschlichen Sprachbaues und ihren Einfluß auf die geistige Entwicklung des Menschengeschlechts, Berlin / Despre diversitatea structurală a limbilor și influența ei asupra dezvoltării spirituale a umanității, versiune românească, introducere, notă asupra traducerii, tabel cronologic, bibliografie și indici de E. Munteanu, București, Humanitas.

ILR I = Densusianu, O., Istoria limbii române, ediție îngrijită și traducere în limba română de J. Byck, vol. I, Originile, Editura Științifică, București, 1961.

ILR II = Densusianu, O., Istoria limbii române, ediție îngrijită și traducere în limba română de J. Byck, vol. II, Secolul al XVI-lea, Editura Științifică, București, 1961.

Gafton, Al. (2010). Consecințele profunde ale contactelor lingvistice, în „Studii de limbă română. Omagiu profesorului Grigore Brâncuș”, Editura Universității din București, p. 77-100.

Gheție, I. \& Mareș, Al. (1974). Graiurile dacoromâne în secolul al XVI-lea, Editura Academiei, București.

Gombocz, Z. (1898). A jelenkori nyelvészet alapelvei, în MNYR, XXVII, p. 6-13, 53-61, 97-103, 193-201, 339-43, 433-8, 481-6.

Gombocz, Z. (1997). Jelentéstan és nyelvtörténet. Válogatott tanulmányok, Akadémiai Kiadó, Budapest.

Graur, Al. (1954). Incercare asupra fondului principal lexical al limbii române, Editura Academiei, București.

Király, F. (1990). Contacte lingvistice. Adaptarea fonetică a imprumuturilor românești de origine maghiară, Editura Facla, Timișoara.

Mândrescu, S.C. (1892). Elemente ungurești în limba română, București.

Meillet, A. (1905-1906). Comment les mots changent de sens, în „L'Année sociologique”, Felix Alcan, Paris, p. 1-38.

Meillet, A. (1948). Linguistique historique et linguistique générale, E. Champion, Paris.

Munteanu, E. (2008). Lexicologie biblică românească, Humanitas, București. 
Niculescu, Al. (2005). Romania hungarica - contacte lingvistice şi culturale româno-maghiare, în „L'altra latinita. Storia linguistica del romeno tra Oriente e Occidente”, Verona, Edizioni Fiorini, 2007; apărut și ca articol în „Studia Universitatis Petru Maior," Series Philologia, nr. 4, 2005, p. 112-137.

Pamfil, V. (1958). Elemente regionale în lexicul „Paliei de la Orăștie”, în CL, III, p. 227-248.

Paul, H. (1886). Prinzipien der Sprachgeschichte, ediția a doua, Max Niemeyer, Halle.

Pușcariu, S. (1940). Limba română, vol. I. Privire generală, București.

Rosetti, Al. (1931). Limba română în secolul al XVI-lea, Editura „Cartea românească”, București.

Simonyi, Zs. (1916). Jelentéstani szempontok, Magyar Tudományos Akadémia, Budapest, în „Értekezések a Nyelv- és Széptudományok köréből”, XXIII (1914-1921), nr. 3, p. 1-42.

Steinthal, H. (1855). Grammatik, Logik, und Psychologie, ibre Principien und ibr Verbältniss zu einander, Ferd. Dümmler, Berlin.

Steinthal, H. (1865). Zeitschrift für Völkerpsychologie und Sprachwissenschaft, Ferd. Dümmler, Berlin.

Vendryes, J. (1921). Le langage: introduction linguistique à l'histoire, Renaissance du livre, Paris.

Wundt, W. (1893). Logik, ediția a treia (1908), Verlag von Ferdinand Enke, Stuttgart.

Wundt, W. (1904). Völkerpsychologie. Eine Untersuchung der Entwicklungsgesetze von Sprache, Mythus und Sitte. Erster Band. Die Sprache, ediția a doua revizuită, Verlag von Wilhelm Engelmann, Leipzig.

Zolnai, B. (1920). Esztétikai szempontok a nyelvtudományban, în MNY, XVI (editat și în Nyelv és stílus, Gondolat, Budapest, 1957). 